\title{
Land use impact on soil physical quality and soil structure in three highland watersheds of Ethiopia
}

\begin{abstract}
Continuous monitoring of soil physical quality is essential in determining sustainability of land use in natural and managed ecosystems particularly; mountainous systems such as the Ethiopian highlands, where soil deterioration and degradation can become major threats to ecosystem and productivity. This study focused on assessment of soil physical quality (SPQ) by comparing values of soil indicator properties to their corresponding 'ideal ranges' established in literature and determining soil structural stability and aggregate associated carbon as influenced by land use types. It further employs factor analysis to identify appropriate SPQ indicators and soil structural indices that are dominantly influenced by each land use type in the three watersheds (namely; Jeldu, Diga and Fogera) of the Ethiopian highlands. Surface soil samples were collected from four adjacent agricultural land use types (namely; Grass fallow, Tree fallow, Homestead and Continuous field cropping) within each of the three watersheds for study of Dexter "S" index, aggregate associated carbon and aggregate stability and other SPQ indicators. Results revealed that soils were only adequate in Relative Field Capacity and Plant Available Water Capacity in all watersheds. The soils of the watersheds still maintained good physical quality but there are strong indications of low soil structural resilience and tendency to degrade. Factor analysis grouped SPQ indicators and structural indices into three factors: (Factor 1) structural stability (with soil organic carbon, aggregate associated organic carbon and aggregate size being the most dominant soil quality indicators); no dominant attribute for Factor 2 and Factor 3 is mainly soil texture (with clay being the most dominant). Soil improvement programme in the watersheds lies in management practices that will promote proper management of organic carbon as it is the principal SPQ indicator that influenced variation in other soil attributes.
\end{abstract}

Keywords: blue nile, organic carbon, fallow, factor analysis, aggregate size distribution
Volume I Issue 4 - 2014

\author{
Ogunwole JO,' Sharma BR, ${ }^{2}$ McCartney MP, ${ }^{3}$ \\ Zemadim B, ${ }^{4}$ Leta $\mathrm{G}^{5}$ \\ 'Department of Crop Production and Protection, Federal \\ University, Dutsin-Ma, Nigeria \\ ${ }^{2}$ Asia Office, International Water Management Institute (IWMI), \\ India \\ ${ }^{3}$ Laos Office, International Water Management Institute (IWMI), \\ India \\ ${ }^{4}$ West and Central Africa Office, International Crops Research \\ Institute for The Semi-Arid Tropics (ICRISAT), India \\ ${ }^{5}$ East Africa Office, International Water Management Institute \\ (IWMI), Ethiopia
}

\begin{abstract}
Correspondence: Joshua $O$ Ogunwole, Department of Crop Production and Protection, Faculty of Agriculture and Agricultural Technology, Federal University, Dutsin-Ma, PMB 500 I, Katsina State, Nigeria, Tel 234-805-822-0007, Email ogunwolejo@hotmail.com
\end{abstract}

Received: July 25, 2014 | Published: August 07, 2014

\begin{abstract}
Abbreviations: SPQ, soil physical quality; SWRC, soil water release curve; AC, air capacity; SOC, soil organic carbon; SI, soil structural index; MWD, mean weight diameter; PCA, principal component analysis; PAWC, plant available water capacity; RFC, relative field capacity; masl, metres above sea level; ha, hectare; OC, organic carbon; $\mathrm{BD}$, bulk density; RFC, relative field capacity
\end{abstract}

\section{Introduction}

Increasing awareness of the several ecological and social functions of the soil has fueled interest in the assessment of soil quality. ${ }^{1}$ Soil quality has been defined as 'capacity of a specific kind of soil to function, within natural and managed ecosystem boundaries, to sustain plant and animal productivities; maintain or enhance water and air qualities and support human health and habitation'. ${ }^{2}$ A soil with good quality possesses major attributes for good agricultural production and may not be prone to wind and/or water erosion. On the basis of this definition, it is evidently clear that agricultural production cannot be intensified without regard for the soils bearing capacity. The European Commission on soil protection strategy addresses 'biomass production' as a main soil function which must be maintained sustainably.,4 This 'productivity function' relates to the earlier definition of soil quality. ${ }^{5}$

Soil quality is usually segmented into 'physical, chemical and biological' quality indicators. ${ }^{6}$ The soil quality concept that provides a tool to help quantify the physical response of soil to land use changes and soil/crop management practices is the soil physical quality (SPQ) indicators. It primarily refers to soil strength, fluid transmission and storage characteristics in crop's root zone. Land use changes and soil management practices can potentially alter SPQ thereby, influencing basic soil functions such as: moderating and partitioning water, solute movement, and their redistribution and supply to plants; filtering, buffering, immobilizing organic and inorganic materials; promoting and providing resistance to erosion. ${ }^{2}$ Soil physical quality can influence structural stability of soils. Increased aggregation and stability of aggregates with organic carbon sequestration have been identified as key indicators for evaluating soil quality. ${ }^{7,8}$ It is therefore, important to evaluate modifications that long term land use types can produce on soil aggregate dynamics and SPQ. Further, a new SPQ indicator referred to as Dexter 'S-index, S-value or S-theory' has been defined $^{9}$ at the inflection point of the soil water release curve (SWRC), as the slope of the SWRC $(\log h, \theta)$ at that point. Reports abound that the S-index is a robust indicator of soil physical quality in structured soils. ${ }^{10}$

In developing countries like Ethiopia, owing to population pressure and higher dependence on agriculture, increase in agricultural yield trends is lagging behind expected demands; resulting in degradation of natural resources which has undermine production capacity particularly; in the highlands. ${ }^{11}$ The highland regions of Ethiopia 
are critical to the country's socioeconomic development as they are areas of recreation and tourism, centers of biodiversity and homes to virtually all the farmers. ${ }^{12}$ In spite of these potentials, the highlands are highly sensitive to climate and human interferences. Humandriven changes for the use of land holds wide ranging significance for the structure and function of the highland's ecosystem.

Changes in land use and ecosystems and implications for the country's environmental change and sustainability are a major research concern. This is because the future of sustainable agricultural productivity and poverty alleviation on these highlands lies in appropriate management practices under different land use types that allow agricultural production to coexist in equilibrium with the soil systems. Continuous monitoring of soil structure and quality is therefore; essential to determine extent of soil deterioration and degradation $^{13,14}$ and, the type of soil management interventions to ameliorate the soil conditions. Most of the effects of soil physical quality are more pronounced in the top soil $(0-10 \mathrm{~cm}) \operatorname{layer}^{6,15}$ and; to a large extent, most of the soil management interventions are at that layer.

The study aimed at

i. Measuring the top SPQ attributes along with soil aggregate size distribution and aggregate associated carbon

ii. Comparing the measured soil attributes with ideal or critical levels proposed in literature

iii. Using factor analysis, identify key SPQ indicator(s) and evaluate the influence of watershed location and land use types on SPQ indicators.

\section{Materials and methods}

Three micro-basins nested within the large R. Abay (Blue Nile) basin namely; catchments of Meja River (at Jeldu), Dapo River (at Diga-Nekempte) and; the Mizewa Water shed (at Fogera) (Figure 1) located on the highlands of Ethiopia. Information on elevation, location, precipitation, land uses and types are presented in (Table 1).

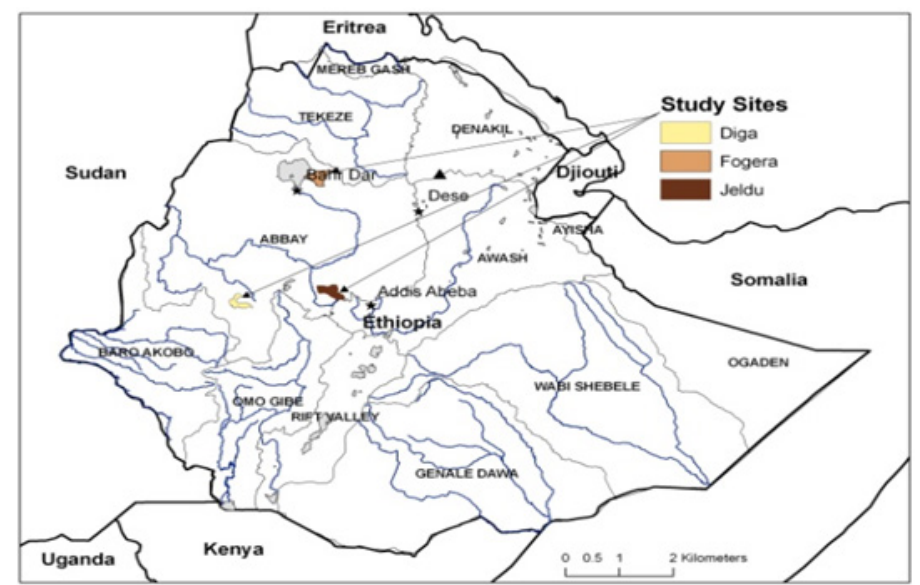

Figure I The location of the three watershed sites in Ethiopia.

Four agricultural land use types namely; grazing fallow, natural forest or planted tree-fallow, continuously cropped fields and homestead cropping, were identified in each micro-basin catchment (Table 2). Selection for sampling considered proximity and slope class. A stratified sampling design ${ }^{16}$ based on elevation and topography was used to collect surface soil samples $(0-15 \mathrm{~cm})$. Four separate composite disturbed samples along with four undisturbed core samples were obtained at random from each of the four sub-plots of each treatment. Replicate undisturbed core samples $(\mathrm{N}=16)$ were wetted, in an aluminum tray, from beneath through capillarity to saturation for about 48 hours. They were later drained on pressure plate apparatus to water suctions (h) of $0,33,100,500$ and $1500 \mathrm{kPa}$. Samples were measured for each soil per suction and, corresponding water contents $(\theta)$ were measured gravimetrically by drying samples at $105^{\circ} \mathrm{C}$ for 24hours. The four replicates of undisturbed soil per treatment were used to generate mean Soil water release curve (SWRC). Soil bulk density ( $\rho b, M g ~ m-3)$ was determined as mass of oven dry soil divided by the volume of the soil core. ${ }^{17}$ Since the soils are of clay texture, Field moisture capacity was defined as $\theta$ at $33 \mathrm{kPa}$. Plant available water capacity $\left(\mathrm{m}^{3} \mathrm{~m}^{-3}\right)$ was determined as the difference between Field moisture capacity ( $\theta$ at $33 \mathrm{kPa}$ ) and Permanent wilting point $(\theta$ at $1500 \mathrm{KPa}$ ); Relative field capacity was estimated as the division of $\theta$ at $33 \mathrm{kPa}$ by $\theta$ at $0 \mathrm{kPa} .{ }^{10}$ Air capacity (AC) was calculated as the difference between $\theta$ at $0 \mathrm{kPa}$ and at $1500 \mathrm{kPa}$. The analysis for the Dexter ' $S$ '-value ${ }^{9}$ was carried out with the experimental data of SWRC ( $h, \theta$ ) adjusted using the van Genuchten ${ }^{18}$ equation with Mualem ${ }^{19}$ restriction in a RETC ${ }^{20}$ computer program. Average bulk density and particle size distribution earlier analyzed were fed into the neural network code of the RETC program to obtaining the various empirical parameters (a $\theta \mathrm{r}, \theta \mathrm{s}, \mathrm{m}$ and $\mathrm{n}$ ) that governs the shape of the SWRC. According to Dexter's theory, the slope at the inflection point (hinf) of the SWRC gives the Dexter 'S-value' and is given by: $\operatorname{Sinf}=-n(\theta s-\theta r)[1+(1 / m)] m+1(1)$

Here, Sinf is the Dexter 'S-value'; $\theta \mathrm{r}$ and $\theta$ s denote soil residual and saturated water contents respectively;

\section{$\mathrm{N}$ and}

$m=1-1 n$

are empirical parameters that govern the shape of SWRC.

Table I Sampling sites showing description of land use pattern, elevation and precipitation

\begin{tabular}{|c|c|c|c|}
\hline $\begin{array}{l}\text { Parameters/ } \\
\text { Watersheds }\end{array}$ & Jeldu & Diga & Fogera \\
\hline Coordinates & $\begin{array}{l}09^{\circ} 15^{\prime} 54.9^{\prime \prime} \mathrm{N} \\
38^{\prime} 04^{\prime} 54.4^{\prime \prime} \mathrm{E}\end{array}$ & $\begin{array}{l}09^{\circ} 01^{\prime} 29.2^{\prime \prime} \mathrm{N} \\
36^{\circ} 27^{\prime} 28^{\prime \prime} \mathrm{E}\end{array}$ & $\begin{array}{l}11^{\circ} 55^{\prime} 24.77^{\prime \prime} \mathrm{N} \\
37^{\circ} 41^{\prime} 40.14^{\prime \prime} \mathrm{E}\end{array}$ \\
\hline Altitude (masl)* & $1328-3200$ & $1200-2342$ & $1784-3600$ \\
\hline $\begin{array}{l}\text { Mean annual } \\
\text { rainfall }(\mathrm{mm})\end{array}$ & $900-1350$ & | $370-2037$ & $974-1516$ \\
\hline $\begin{array}{l}\text { Total land area } \\
\text { (ha) }\end{array}$ & I39,389 & 40,789 & 102,807 \\
\hline \multicolumn{4}{|l|}{$\begin{array}{l}\text { Land use pattern } \\
\text { (\% of land area) }\end{array}$} \\
\hline Arable land & 43.4 & 68.2 & 67.8 \\
\hline Grazing land & 15.3 & 12.2 & 14.6 \\
\hline Forest land & 3.9 & 16.9 & 4.7 \\
\hline Others & 37.4 & 2.6 & 12.8 \\
\hline
\end{tabular}

*masl: metres above sea level; ha, hectare 
Table 2 Summary description of selected land use within each watershed

\begin{tabular}{|c|c|c|}
\hline $\begin{array}{l}\text { Watershed } \\
\text { location }\end{array}$ & Land use & $\begin{array}{l}\text { Description of each land use } \\
\text { system }\end{array}$ \\
\hline \multirow[t]{4}{*}{ Jeldu } & $\begin{array}{l}\text { Natural } \\
\text { grass-fallow }\end{array}$ & $\begin{array}{l}\text { Grazing land for }>40 y r s ; \text { a wet land } \\
\text { with grasses, such as Nut sedge and } \\
\text { Trifolium spp. }\end{array}$ \\
\hline & $\begin{array}{l}\text { Homestead } \\
\text { agriculture }\end{array}$ & $\begin{array}{l}\text { Homestead farm, cropped regularly to } \\
\text { barley and irrigated maize; Farmyard } \\
\text { manure added regularly. }\end{array}$ \\
\hline & $\begin{array}{l}\text { Continuous } \\
\text { cultivation }\end{array}$ & $\begin{array}{l}\text { Farm cropped for }>20 \text { years to } \\
\text { alternate maize and tef with } 4 \text { times } \\
\text { and } 2 \text { times tillage respectively per } \\
\text { annum. Stony and waterlogged. }\end{array}$ \\
\hline & Tree-fallow & $\begin{array}{l}\text { A }>15 \text { years old plantation of } \\
\text { Eucalyptus tree with other species } \\
\text { like Acacia in a mixed plantation cum } \\
\text { natural forest }\end{array}$ \\
\hline \multirow[t]{4}{*}{$\begin{array}{l}\text { Diga- } \\
\text { Nekempte - } \\
\text { Nekempte }\end{array}$} & Tree-fallow & $\begin{array}{l}\text { A mixed natural forest and forest } \\
\text { coffee system; with }>40 \text { years of } \\
\text { establishment; Cordia Africana, Albizia } \\
\text { spp and Croton macrostachyus are } \\
\text { dominant native tree species in the } \\
\text { forest. }\end{array}$ \\
\hline & $\begin{array}{l}\text { Natural grass } \\
\text { fallow }\end{array}$ & $\begin{array}{l}\text { A grazing land previously cropped } \\
\text { to tef under land rotation, common } \\
\text { grasses are Digitaria spp, Cynodon, } \\
\text { Cyperus and spp. }\end{array}$ \\
\hline & $\begin{array}{l}\text { Continuous } \\
\text { cultivation }\end{array}$ & $\begin{array}{l}\text { A continuously cropped farm to } \\
\text { barley; with shifting corralling soil } \\
\text { fertility restoration practice. Signs } \\
\text { of severe erosion with waterlogged } \\
\text { downslope. Guziotia scabra and Bidens } \\
\text { pachyloma are dominant weed species } \\
\text { on the farm. Lands are tilled } 3 \text { times } \\
\text { before seeding; no in-organic fertilizer } \\
\text { applied. Problem with termites and } \\
\text { wild animals. }\end{array}$ \\
\hline & $\begin{array}{l}\text { Homestead } \\
\text { agriculture }\end{array}$ & $\begin{array}{l}\text { A homestead with years of maize } \\
\text { monoculture and; corralling is the } \\
\text { soil fertility restoration practice. } \\
\text { Last corralling was } 4 y r s \text { ago; heavy } \\
\text { infestation by termites and wild } \\
\text { animals. Tillage is four times before } \\
\text { seeding and after crop harvest, one } \\
\text { field plowing is carried out to check } \\
\text { compaction. }\end{array}$ \\
\hline \multirow[t]{4}{*}{ FOGERA } & $\begin{array}{l}\text { Natural tree- } \\
\text { fallow }\end{array}$ & $\begin{array}{l}\text { A long time ( }>10 y r s) \text { Eucalyptus } \\
\text { plantation planted near a stream banks }\end{array}$ \\
\hline & $\begin{array}{l}\text { Continuous } \\
\text { cultivation }\end{array}$ & $\begin{array}{l}\text { A continuous maize field (10-15yrs) } \\
\text { with inorganic fertilizer applications; } \\
\text { no manure amendment. }\end{array}$ \\
\hline & $\begin{array}{l}\text { Natural } \\
\text { grass-fallow }\end{array}$ & $\begin{array}{l}\text { Communal grazing land for I0years } \\
\text { partly waterlogged with the Cynodon } \\
\text { dactylon and Digitaria abyssinica as } \\
\text { common grass species. }\end{array}$ \\
\hline & $\begin{array}{l}\text { Home stead } \\
\text { agriculture }\end{array}$ & $\begin{array}{l}\text { A homestead with years of maize } \\
\text { monoculture and farmyard manure } \\
\text { application. Tillage is four times before } \\
\text { seeding and after crop harvest, one } \\
\text { field plowing is carried out to check } \\
\text { compaction }\end{array}$ \\
\hline
\end{tabular}

Field moist disturbed soil samples were gently crushed to pass a $5-\mathrm{mm}$ sieve and divided into two halves. The first half was air dried and further crushed to pass a $2 \mathrm{~mm}$ sieve after which particle size distribution was determined using the hydrometer method with sodium hexametaphosphate as dispersant ${ }^{21}$ and Soil organic carbon (SOC) determined by aid of the wet oxidation method of Nelson et al. ${ }^{22}$ Soil structural index (SI) was determined by calculation as:

$$
\text { SI }=1.724 \operatorname{SOC}(\text { Silt }+ \text { Clay }) \times 100(2)
$$

A 300 grams soil from the remaining half of the undisturbed soil sample was slaked wetted and wet sieved through a mesh of 2-, 0.25and $0.005-\mathrm{mm} .{ }^{23}$ Wet sieving was continued manually for 3 minutes with 30 oscillations per minutes. Soil aggregates left on each sieve were oven dried, weighed and calculated as proportion of the initial soil weight.

Mean Weight Diameter (MWD) was determined as:

$$
M W D=\sum i=1 \text { nxi } \omega i
$$

Where; $x_{i}$ represents mean diameter of each ith aggregate size fraction and, $\omega_{i}$ is the proportion of total initial weight $(300 \mathrm{~g})$ occurring in the corresponding ith size fraction. The OC content of each aggregate fraction was analyzed by the procedure of Nelson et al. ${ }^{22}$

\section{Data analysis}

Factor (Principal component) analysis was carried out on the soil attributes using covariance (standardized data) matrix of the PASW $18^{24}$ for each location and land use types, and pooled soil attributes from all the three locations and A varimax rotation with Kaiser Normalization ${ }^{25,26}$ was performed in the Principal component analysis (PCA) to investigate the variable or clusters of variables that might explain majority of the total variance.

\section{Results and discussion}

\section{Particle size distribution}

Particle size analysis showed that clay content differed significantly between soils at Fogera and those of Diga-Nekempte and Jeldu (Table 3). Watershed location had no significant effect on silt particle size but the distribution of the sand particle fraction differed significantly; with soils at Fogera recording highest proportion. Silt and clay ratio was significantly higher at Fogera compared to the other two watersheds. Soil textural class showed that soils of Fogera and Jeldu were clays while; Diga-Nekempte was silty clay. Clay particle fraction differed significantly with land use. Soils under continuous cropping recorded $21 \%$ more clay than that of grass fallow. All land use recorded clays as soil textural class except the grass fallow system which supported a silty clay texture. Silt-clay ratio did not differ significantly under land uses but sand particle proportion was significantly lower with continuous cropping.

\section{Soil bulk density}

The soil bulk density is an index of soil quality, an indicator of soil compaction and a determinant of soil's mechanical resistance to root growth. ${ }^{10,27}$ Optimum soil bulk density range for arable field crop is between $0.9-1.2 \mathrm{Mg} \mathrm{m}^{-3} .{ }^{28,29}$ Grass and forest fallows along with the homestead cropping in Jeldu recorded very low soil bulk density values $\left(<0.9 \mathrm{Mg} \mathrm{m}^{-3}\right)$ ranging from $0.71-0.89 \mathrm{Mg} \mathrm{m}^{-3}$ (Table 4). One implication of low soil bulk density is insufficient rootsoil contact $^{6}$ which can consequently lead to poor plant anchorage 
and low soil water retention. In soils with low soil bulk density condition, tall cereals such as maize, sorghum and pearl millet are liable to lodging in cropped fields. In Diga, soil bulk density values were within the critical or optimal range. However, high bulk density values were recorded at Fogera (Table 3). High values of soil bulk density at Fogera were notable in soils under cropping (i.e. homestead and continuous cropping). In well aerated fine textured soils, upper limit for soil bulk density are in the range of $1.25-1.30 \mathrm{Mg} \mathrm{m}^{-3} .{ }^{30}$ Soils with bulk density values $\geq 1.30 \mathrm{Mg} \mathrm{m}^{-3}$ as recorded under cropping at Fogera are indicative of compaction prone soils which will hinder root elongation, reduce aeration and impede water infiltration and movement within the root zone.
On the average within the three watersheds, the soils of the Mizewa river watershed (Fogera) recorded the highest soil bulk density and value was above the upper limit of the optimal range (Table 5). On the other hand, Meja river watershed (Jeldu) had the lowest soil bulk density value which is at par with the lower limit of the optimal range. When soil bulk density values were compared among land use types across watersheds; cultivation or cropping increased soil bulk density values as table showed that soil bulk density values increased from fallow to cropping. Even though, all soil bulk density values were within optimal range (Table 3), soils under continuous cropping was at par with the upper soil bulk density limit.

Table 3 Soil texture and selected soil physical quality indicator values relative to optimal indicator ranges (proposed in literature) across land use and watersheds of the Ethiopian highland

\begin{tabular}{|c|c|c|c|c|c|c|c|c|c|c|}
\hline $\begin{array}{l}\text { Watershed } \\
\text { location } \\
\text { and land } \\
\text { use }\end{array}$ & & Texture & & $\begin{array}{l}\text { Organic } \\
\text { carbon } \\
\text { (wt. \%) }\end{array}$ & $\begin{array}{l}\text { Bulk } \\
\text { density } \\
\text { (Mg m-3) }\end{array}$ & $\begin{array}{l}\text { Plant } \\
\text { available } \\
\text { water } \\
\text { capacity } \\
\text { (PAWC, } \\
\text { m3 m-3) }\end{array}$ & $\begin{array}{l}\text { Structural } \\
\text { stability } \\
\text { index (SI, } \\
\%)\end{array}$ & $\begin{array}{l}\text { Air } \\
\text { capacity } \\
\text { (AC, m3 } \\
\text { m-3) }\end{array}$ & $\begin{array}{l}\text { Dexter } \\
\text { 'S' } \\
\text { index }\end{array}$ & $\begin{array}{l}\text { Relative } \\
\text { field } \\
\text { capacity } \\
\text { (RFC) }\end{array}$ \\
\hline & $\begin{array}{l}\text { Sand } \\
\text { (wt. } \\
\%)\end{array}$ & $\begin{array}{l}\text { Silt (wt. } \\
\% \text { ) }\end{array}$ & Clay & t. \%) & & & & & & \\
\hline \multicolumn{11}{|l|}{$\begin{array}{l}\text { Across land } \\
\text { use }\end{array}$} \\
\hline Jeldu & 14.4 & 34.5 & 51.1 & 0.61 & 0.9 & 0.22 & 1.35 & 0.024 & 0.049 & 0.94 \\
\hline Diga & 10.8 & 39.1 & 50.1 & 0.27 & 1.09 & 0.282 & 0.54 & 0.047 & 0.05 & 0.91 \\
\hline Fogera & 16.4 & 36.1 & 45 & 0.15 & 1.22 & 0.26 & 0.32 & 0.029 & 0.042 & 0.93 \\
\hline \multicolumn{11}{|l|}{$\begin{array}{l}\text { Across } \\
\text { watershed }\end{array}$} \\
\hline Grass fallow & 15.5 & 39.9 & 44.4 & 0.55 & 1.02 & 0.251 & 1.25 & 0.028 & 0.047 & 0.93 \\
\hline Forest fallow & 14.8 & 37 & 48.2 & 0.3 & 0.98 & 0.233 & 0.63 & 0.036 & 0.047 & 0.92 \\
\hline $\begin{array}{l}\text { Homestead } \\
\text { cropping }\end{array}$ & 13.7 & 37.3 & 49 & 0.3 & 1.08 & 0.247 & 0.6 & 0.034 & 0.046 & 0.93 \\
\hline $\begin{array}{l}\text { Continuous } \\
\text { cropping }\end{array}$ & 11.3 & 35.2 & 53.5 & 0.24 & 1.2 & 0.286 & 0.46 & 0.036 & 0.048 & 0.92 \\
\hline $\begin{array}{l}\text { Optimal } \\
\text { range* }\end{array}$ & - & - & - & 5-Mar & $0.9-1.2$ & $\geq 0.15$ & $>7$ & $\geq 0.15$ & $\geq 0.035$ & $0.6-0.7$ \\
\hline
\end{tabular}

*Source of optimal range: ${ }^{10}$

Table 4 Soil texture and selected soil physical quality indicator values relative to optimal indicator ranges (proposed in literature) in the three watersheds of the Ethiopian highland

\begin{tabular}{|c|c|c|c|c|c|c|c|c|c|c|}
\hline $\begin{array}{l}\text { Watershed } \\
\text { location } \\
\text { and land } \\
\text { use }\end{array}$ & & Texture & & $\begin{array}{l}\text { Organic } \\
\text { carbon } \\
\text { (wt. \%) }\end{array}$ & $\begin{array}{l}\text { Bulk } \\
\text { density } \\
(\mathrm{Mg} \\
\left.\mathrm{m}^{-3}\right)\end{array}$ & $\begin{array}{l}\text { Plant available } \\
\text { water capacity } \\
\text { (PAWC, } \mathrm{m}^{3} \\
\mathrm{~m}^{-3} \text { ) }\end{array}$ & $\begin{array}{l}\text { Structural } \\
\text { stability } \\
\text { index (SI, } \\
\%)\end{array}$ & $\begin{array}{l}\text { Air } \\
\text { capacity } \\
\left(\mathrm{AC}, \mathrm{m}^{3}\right. \\
\left.\mathrm{m}^{-3}\right)\end{array}$ & $\begin{array}{l}\text { Dexter } \\
\text { 'S' } \\
\text { index }\end{array}$ & $\begin{array}{l}\text { Relative } \\
\text { field } \\
\text { capacity } \\
\text { (RFC) }\end{array}$ \\
\hline & $\begin{array}{l}\text { Sand } \\
\text { (wt. } \\
\% \text { ) }\end{array}$ & $\begin{array}{l}\text { Silt (wt. } \\
\% \text { ) }\end{array}$ & $\begin{array}{l}\text { Clay } \\
\text { (wt. } \\
\% \text { ) }\end{array}$ & & & & & & & \\
\hline
\end{tabular}

\section{Jeldu}

Grass fallow

$\begin{array}{llll}26 & 38 & 36 & 1\end{array}$

1.19

$0.7 \mid$

0.17

2.86

$0.021 \quad 0.051$

0.95 
Table Continued..

\begin{tabular}{|c|c|c|c|c|c|c|c|c|c|c|}
\hline Forest fallow & 16 & 36 & 48 & 0.48 & 0.82 & 0.20 & 1.03 & 0.032 & 0.049 & 0.93 \\
\hline $\begin{array}{l}\text { Homestead } \\
\text { cropping }\end{array}$ & 12.5 & 34.5 & 53 & 0.50 & 0.89 & 0.21 & 0.99 & 0.019 & 0.053 & 0.96 \\
\hline $\begin{array}{l}\text { Continuous } \\
\text { cropping }\end{array}$ & 3 & 29.5 & 67.5 & 0.29 & 1.18 & 0.30 & 0.53 & 0.026 & 0.045 & 0.94 \\
\hline \multicolumn{11}{|l|}{ Diga } \\
\hline Grass fallow & 6.5 & 37 & 56.5 & 0.26 & 1.19 & 0.32 & 0.49 & 0.036 & 0.050 & 0.92 \\
\hline Forest fallow & 10 & 40 & 50 & 0.27 & 1.06 & 0.28 & 0.52 & 0.053 & 0.051 & 0.90 \\
\hline $\begin{array}{l}\text { Homestead } \\
\text { cropping }\end{array}$ & 12 & 40.5 & 47.5 & 0.28 & 1.02 & 0.25 & 0.55 & 0.057 & 0.047 & 0.89 \\
\hline $\begin{array}{l}\text { Continuous } \\
\text { cropping }\end{array}$ & 14.5 & 39 & 46.5 & 0.29 & I.II & 0.28 & 0.59 & 0.043 & 0.052 & 0.91 \\
\hline \multicolumn{11}{|l|}{ Fogera } \\
\hline Grass fallow & 14 & 35.5 & 40.5 & 0.20 & 1.16 & 0.27 & 0.40 & 0.026 & 0.039 & 0.93 \\
\hline Forest fallow & 18.5 & 35 & 46.5 & 0.17 & 1.06 & 0.22 & 0.35 & 0.025 & 0.043 & 0.93 \\
\hline $\begin{array}{l}\text { Homestead } \\
\text { cropping }\end{array}$ & 16.5 & 37.5 & 46.0 & 0.13 & 1.32 & 0.27 & 0.26 & 0.026 & 0.039 & 0.93 \\
\hline $\begin{array}{l}\text { Continuous } \\
\text { cropping }\end{array}$ & 16 & 38 & 46.5 & 0.12 & 1.33 & 0.27 & 0.26 & 0.039 & 0.047 & 0.92 \\
\hline $\begin{array}{l}\text { Optimal } \\
\text { range* }\end{array}$ & - & - & - & $3-5$ & $0.9-1.2$ & $\geq 0.15$ & $>7$ & $\geq 0.15$ & $\geq 0.035$ & $0.6-0.7$ \\
\hline
\end{tabular}

*Source of optimal range: ${ }^{10}$

Table 5 Eigenvalue, proportion and cumulative variance explained by factor analysis using covariance matrix (standardized data) for all and each of the three watersheds.

\begin{tabular}{|c|c|c|c|}
\hline \multicolumn{4}{|l|}{ All locations } \\
\hline $\begin{array}{l}\text { Principal } \\
\text { Component } \\
\text { (PC) }\end{array}$ & Eigenvalue & $\begin{array}{l}\text { Percent of } \\
\text { Variance }\end{array}$ & $\begin{array}{l}\text { Percent } \\
\text { Cumulative } \\
\text { Variance }\end{array}$ \\
\hline PC I & 5.62 & 31.21 & 31.21 \\
\hline PC 2 & 2.20 & 12.23 & 43.44 \\
\hline PC 3 & 1.83 & 10.16 & 53.60 \\
\hline \multicolumn{4}{|l|}{ Jeldu } \\
\hline PC I & 5.49 & 30.48 & 30.48 \\
\hline PC 2 & 5.08 & 28.22 & 58.70 \\
\hline \multicolumn{4}{|l|}{ Diga } \\
\hline PC I & 3.36 & 18.65 & 18.65 \\
\hline PC 2 & 3.30 & 18.34 & 37.00 \\
\hline PC 3 & 2.22 & 12.33 & 49.33 \\
\hline \multicolumn{4}{|l|}{ Fogera } \\
\hline PC I & 4.83 & 26.83 & 26.83 \\
\hline PC 2 & 2.73 & 15.16 & 42.00 \\
\hline
\end{tabular}

\section{Soil organic carbon}

Soil organic carbon (SOC) is one of the principal components and a critical parameter of soil quality since SOC content correlates strongly with many soil properties and functions such as soil porosity, soil structural stability and water holding capacity. Optimal range has been put at $3-5 \mathrm{wt} \%$ organic carbon content for establishment and maintenance of plants in urban parks, sport fields to mention a few. ${ }^{6}$ Even though, that SOC criterion cannot be directly adopted for field crops, it can serve as a guide. Greenland ${ }^{31}$ and Sojka and Upchurch $^{32}$ proposed an optimal range of $2.3-6.0 \mathrm{wt} \%$; below which tillage induced soil loss may occur and beyond which fine textured soils become prone to compaction and soil incorporated pesticide absorption.

Soil OC content was far below the lower critical limit in all land use types at all watersheds (Table 4). Grass fallow at Jeldu recorded the highest accumulation of SOC (1.19wt.\%) followed by Homestead cropping. The SOC content in Diga was similar across land use types ranging from $0.26-0.29 w t . \%$. The fallows (grass and forest) at Fogera accumulated more SOC than the other land use types. Across land use, SOC content was highest in Jeldu (0.61wt. \%) followed by Diga and lowest SOC accumulation was at Fogera (Table 3). When SOC content was considered across watersheds, grass fallow supported highest accumulation while continuous cropping recorded the lowest SOC content.

\section{Air- and plant available water- capacity}

The air capacity (AC) of a soil is an index of the aeration capability of the soil. In fine textured soil, $\mathrm{AC}=0.15 \mathrm{~m}^{3} \mathrm{~m}^{-3}$ is regarded as critical limit, to compensate for low gas diffusion rates and respiration 
demands of soil biota [33]. The AC was very low in all the soils of the various land use types, ranging from $0.019-0.057 \mathrm{~m}^{3} \mathrm{~m}^{-3}$ (Table 4). Homestead cropping at Jeldu recorded the lowest AC value however, when considered across watersheds, forest fallow and continuous cropping recorded the highest value of $\mathrm{AC}\left(0.036 \mathrm{~m}^{3} \mathrm{~m}^{-3}\right)$ which was far lower than the critical limit. However, across land use types, AC values of soils are in the order of Diga $>$ Fogera $>$ Jeldu (Table 3 ).

The plant available water capacity (PAWC) ranged from 0.17 $0.20 \mathrm{~m}^{3} \mathrm{~m}^{-3}$ in the soils under land use type and watersheds. With PAWC value of $0.15 \mathrm{~m}^{3} \mathrm{~m}^{-3}$ identified ${ }^{33}$ as limiting value, any value below this value is considered poor. Across watershed and land use, PAWC values showed that these fine textured soils are ideal $\left(>0.20 \mathrm{~m}^{3} \mathrm{~m}^{-3}\right)$ for maximum root growth and function.

\section{Soil structural stability}

The soil structural stability index (SI) is a measure of structural degradation in soils. A SI $\leq 5 \%$ is indicative of a structurally degraded soil while, SI of 5-7\% indicates high risk of structural degradation due to insufficient organic carbon. ${ }^{6}$ Results of SI obtained in this study showed that all the soils under the various land use and in all three watersheds are structurally degraded (Table 4). Degradation is more pronounced with soils under continuous cropping at Jeldu and Fogera. In Diga, soils under grass fallow are the most degraded. Across land use, soils of Fogera watershed were the most degraded followed by those of Diga and Jeldu in that order. The soils under cropping (i.e., homestead and continuous cropping) were more degraded than those under fallow across the watershed (Table 3).

\section{Relative field capacity}

The relative field capacity (RFC) indicates the soil's ability to store both water and air relative to the soil's total pore volume. For all the soils in this study, RFC value was greater than 7 (Tables 3) (Table 4) indicating an optimal balance between soil water and soil air capacity within the root zone of mineral soil of rain fed agriculture. ${ }^{34}$

The Dexter 'S' value (hereafter referred to as "S-value") ranged from 0.039 to 0.053 in soil under the various land use of the three watersheds. Homestead cropping at Jeldu recorded highest S-value followed closely by continuous cropping at Diga (Table 4). Lowest $\mathrm{S}$-value was recorded for grass fallow and homestead cropping at Fogera. Across land use, soils of Diga had the highest S-value, followed by those of Jeldu and Fogera. Across watersheds, S-value was generally similar, with continuous cropping recording the highest value followed closely by the fallows and homestead cropping (Table 3 ). Soils with S-value $<0.020$ is considered very poor and the SPQ is considered degraded [9]. However, a soil considered of good structural quality has $\mathrm{S}$-value $\geq 0.050$ while, soil with $0.035 \leq \mathrm{S}$-value $<0.050$ is of good physical quality. Agricultural soils of both temperate and tropical regions tend to fall within S-value range of $0.007 \leq \mathrm{S}$-value $\leq 0.14 .{ }^{35}$

\section{Grouping of soil properties through factor analysis}

The Principal component analysis (PCA hereafter) is a useful tool for extracting leading patterns from high-dimensioned data. Eigenvalues from the covariance analysis of pooled standardized data of soil attributes from the three locations indicated that the first three principal components (PCs) accounted for $53.6 \%$ of the total variance. When analyzed for each location, the first PC explained $58.7 \%$ of total variance for Jeldu while, eigenvalues for Dapo and Fogera were two and three PCs and; they were responsible respectively, for $49.33 \%$ and $42 \%$ (Table 5 ) of the total variance of each location. The magnitude of the loading (eigenvalues) was the basis for interpreting the relationship between soil attributes and PCs. A soil attribute was assigned to a PC for which its eigenvalue (loading) was highest and a high communality estimate is an indication that a high portion of variance was explained by the factor. As such a high estimate of communality attracts a higher preference over a low estimate. ${ }^{36}$

In the PCA of the pooled soil attributes (i.e. for the three locations), PC 1 explained $31.21 \%$ (Table 5) of the variance has high positive loading $(>0.9)$ for total organic carbon and aggregate associated carbon. Silt was the least important soil attribute (Table 6) due to its lowest communality estimate $(0.027)$. The $\mathrm{PC} 1$ also has positive loading $(\geq 0.58)$ from MWD and large macroaggregates (i.e. aggregate size of 5-2mm). We named PC1 'Aggregate stabilization' since organic carbon and aggregate associated organic carbons have the highest contributions to the variance from their communality estimates. Complex interactions exist between organic carbon storage and aggregate stability. Soil organic matter play major role in stabilization of aggregates and this stabilization can, in turn, reinforce soil organic carbon storage by diminishing organic carbon loss by erosion ${ }^{37}$ and/or through improvement of physically protected organic carbon against mineralization. ${ }^{38}$ There was no dominant soil attribute in PC2 while PC3 explained $10.16 \%$ of variance with high negative loading from sand (Tables 5) (Table 6) and high positive loading from clay (0.895). The PC3 was called the 'soil texture' because it explained variation in sand and clay fractions of soils.

Table 6 Proportion of variance using varimax rotation and communality estimates of combined SPQ and soil structural indicators of all watershed locations

\begin{tabular}{|c|c|c|c|c|}
\hline Indicators* & PC I & PC 2 & PC 3 & Communality \\
\hline OC (wt \%) & 0.909 & 0.261 & -0.017 & 0.896 \\
\hline Sand & 0.451 & 0.188 & -0.817 & 0.907 \\
\hline Silt & 0.096 & -0.135 & -0.009 & 0.027 \\
\hline Clay & -0.372 & -0.159 & 0.895 & 0.966 \\
\hline $\mathrm{BD}\left(\mathrm{Mg} \mathrm{m}^{-3}\right)$ & $-0.72 I$ & -0.114 & 0.082 & 0.539 \\
\hline MWD (mm) & 0.580 & 0.363 & -0.094 & 0.477 \\
\hline Dexter S-value & 0.217 & 0.178 & 0.217 & 0.126 \\
\hline$A C\left(m^{3} m^{-3}\right)$ & -0.262 & 0.153 & -0.141 & 0.112 \\
\hline PAWC $\left(\mathrm{m}^{3} \mathrm{~m}^{-3}\right)$ & -0.636 & -0.043 & 0.348 & 0.528 \\
\hline RFC & 0.272 & -0.099 & 0.188 & 0.119 \\
\hline SI (\%) & 0.898 & 0.258 & -0.105 & 0.884 \\
\hline \multicolumn{5}{|l|}{ Aggregate size } \\
\hline $5-2 \mathrm{~mm}$ & 0.593 & 0.340 & -0.145 & 0.488 \\
\hline $2-0.25 \mathrm{~mm}$ & -0.062 & 0.106 & 0.214 & 0.061 \\
\hline $0.25-0.005 \mathrm{~mm}$ & -0.347 & -0.264 & 0.054 & 0.193 \\
\hline$<0.00 \mathrm{~mm}$ & -0.491 & -0.373 & -0.097 & 0.389 \\
\hline \multicolumn{5}{|l|}{$\begin{array}{l}\text { Aggregate associated } \\
O C\end{array}$} \\
\hline$O C(5-2 m m)$ & 0.936 & -0.349 & -0.017 & 0.998 \\
\hline $\mathrm{OC}(2-0.25 \mathrm{~mm})$ & 0.969 & 0.112 & 0.032 & 0.950 \\
\hline $\mathrm{OC}(0.25-0.005 \mathrm{~mm})$ & 0.943 & 0.303 & 0.090 & 0.990 \\
\hline
\end{tabular}

Rotated, standardized data with loadings higher than 0.5 are in bold and italics. *OC, organic carbon; MWD, mean weight diameter; AC, air capacity; PAWC, plant available water capacity; BD, bulk density; RFC, relative field capacity; SI, structural stability index; OC (5-2mm), OC (2- 0.25mm), OC (0.25-0.005 mm) - Organic carbon in aggregate fractions, $(5-2 \mathrm{~mm}),(2-0.25 \mathrm{~mm}),(0.25 \mathrm{~mm}-$ $0.05 \mathrm{~mm}$ ). 
Within land use types, continuous cropping and forest fallow indicated that their first three PCs explained 66.51- and 60.03-\% respectively, of the variance of data. Homestead cropping showed that the first two PCs accounted for $42.78 \%$ while, in grass fallow, the only PC explained $57.68 \%$ (Table 7) of the variance. In the only PC for grass fallow, high positive loadings were recorded for organic carbon (0.965), aggregate associated organic carbon, large macroaggregate fraction (i.e. aggregate size $5-2 \mathrm{~mm}$ ) and structural stability index while, high negative loading was recorded for soil bulk density (-0.925), PAWC and silt+clay fraction (i.e. aggregate size $<0.005 \mathrm{~mm}$ ). Clay particle and microaggregate (aggregate size
$0.25-0.005 \mathrm{~mm}$ ) fraction recorded moderate negative loadings (Table 8). Forest fallow land use recorded high positive loadings for microand macro-aggregate associated organic carbon and SOC, moderate loading for large macroaggregate associated carbon and negative loadings for soil bulk density and PWAC (PC1). Silt, clay and microaggregate had positive loading in PC2 while, MWD and large macroaggregates recorded negative loadings. Soil porosity in the form of AC and PAWC recorded positive loadings in this PC 3. In both continuous- and homestead cropping, organic carbon and aggregate associated organic carbon accounted for the positive loadings in their PC1 (Table 8).

Table 7 Eigenvalue, proportion and cumulative variance explained by factor analysis using covariance matrix (standardized data) for surface soils grouped based on land use type

\begin{tabular}{llll}
\hline Forest fallow & & & \\
\hline Principal Component (PC) & Eigenvalue & Percent of Variance & $\begin{array}{l}\text { Percent Cumulative } \\
\text { Variance }\end{array}$ \\
\hline PC I & 4.70 & 26.12 & 26.12 \\
PC 2 & 3.67 & 20.38 & 46.50 \\
PC 3 & 2.44 & 13.53 & 60.03 \\
Homestead cropping & & & \\
PC 1 & 4.02 & 22.36 & 22.36 \\
PC 2 & 3.68 & 20.43 & 42.78 \\
Continous cropping & & & 24.84 \\
PC I & 4.47 & 24.84 & 45.82 \\
PC 2 & 3.78 & 20.98 & 66.51 \\
PC 3 & 3.72 & 20.69 & \\
Grass fallow & & & 57.82 \\
PC 1 & 10.41 & 57.82 &
\end{tabular}

Table 8 Correlations between soil structure and SPQ indicators and rotated principal components (PCs) for surface soils grouped based on land use type

\begin{tabular}{|c|c|c|c|c|c|c|c|c|c|}
\hline \multirow[t]{2}{*}{ Indicators* } & \multirow{2}{*}{$\begin{array}{l}\text { Forest } \\
\text { PC I }\end{array}$} & \multicolumn{2}{|l|}{ Fallow } & \multirow{2}{*}{$\begin{array}{l}\text { Continuous } \\
\text { PC I }\end{array}$} & \multicolumn{2}{|l|}{ Cropping } & \multirow{2}{*}{$\begin{array}{l}\text { Homestead } \\
\text { PC I }\end{array}$} & \multirow{2}{*}{$\begin{array}{l}\text { Cropping } \\
\text { PC } 2\end{array}$} & \multirow{2}{*}{$\begin{array}{l}\text { Grass Fallow } \\
\text { PC I }\end{array}$} \\
\hline & & PC 2 & PC 3 & & PC 2 & PC 3 & & & \\
\hline OC (wt \%) & 0.837 & --- & --- & 0.693 & --- & 0.595 & 0.734 & --- & 0.965 \\
\hline Sand & --- & -0.966 & --- & -0.885 & --- & & --- & -- & 0.764 \\
\hline Silt & --- & 0.508 & --- & -0.733 & --- & & --- & 0.615 & --- \\
\hline Clay & --- & 0.908 & --- & 0.908 & --- & & --- & -0.773 & -0.577 \\
\hline $\mathrm{BD}\left(\mathrm{Mg} \mathrm{m}^{-3}\right)$ & -0.769 & --- & --- & --- & -0.549 & & -0.676 & -- & -0.925 \\
\hline MWD (mm) & --- & -0.505 & --- & --- & --- & 0.807 & --- & -- & 0.867 \\
\hline Dexter S-value & --- & --- & --- & --- & --- & --- & --- & -0.504 & --- \\
\hline$A C\left(m^{3} m^{-3}\right)$ & --- & --- & 0.545 & -- & --- & --- & -- & -- & --- \\
\hline PAWC $\left(\mathrm{m}^{3} \mathrm{~m}^{-}\right)$ & -0.515 & --- & 0.521 & 0.545 & --- & --- & --- & --- & -0.849 \\
\hline RFC & --- & --- & --- & 0.526 & --- & --- & --- & --- & --- \\
\hline SI (\%) & --- & --- & --- & $0.5 I I$ & --- & 0.652 & 0.742 & --- & 0.945 \\
\hline \multicolumn{10}{|l|}{ Aggregate size } \\
\hline $5-2 \mathrm{~mm}$ & --- & -0.500 & --- & --- & --- & 0.752 & -- & --- & 0.884 \\
\hline $2-0.25 \mathrm{~mm}$ & --- & --- & --- & --- & --- & --- & --- & -- & --- \\
\hline $0.25-0.005 \mathrm{~mm}$ & --- & 0.514 & --- & --- & --- & -0.777 & --- & -- & -0.699 \\
\hline$<0.005 \mathrm{~mm}$ & --- & --- & -0.628 & --- & --- & -0.579 & $-0.52 I$ & --- & -0.712 \\
\hline
\end{tabular}


Table Continued..

\begin{tabular}{lllllllllll} 
Indicators* & Forest & Fallow & & Continuous & Cropping & & Homestead & Cropping & Grass Fallow \\
\cline { 2 - 10 } & PC I & PC 2 & PC 3 & PC I & PC 2 & PC 3 & PC I & PC 2 & PC I \\
\hline OC $(5-2 \mathrm{~mm})$ & $\mathbf{0 . 6 2 8}$ & --- & -0.730 & $\mathbf{0 . 7 1 0}$ & $\mathbf{0 . 6 7 0}$ & --- & 0.863 & --- & 0.976 \\
OC $(2-0.25 \mathrm{~mm})$ & 0.945 & --- & --- & 0.696 & --- & 0.613 & 0.961 & --- & 0.982 \\
OC $(0.25-0.005 \mathrm{~mm})$ & $\mathbf{0 . 8 8 3}$ & --- & --- & 0.751 & --- & 0.613 & 0.949 & --- & 0.968 & \\
\hline
\end{tabular}

\section{Conclusion}

None of the soils demonstrate clear superiority in all the SPQ indicators and structural indices. Factor analysis was therefore; employed to group SPQ indicators and soil structural indices into three factors. Except for Factor (PC) 2, all factors related to one or more SPQ or soil structural indices. From the results of communality estimates and the factor loadings, measured SOC and aggregate associated organic carbon influence SPQ and soil structural stability. Soil aggregation and aggregate stability are influenced largely by SOC and to some extent, clay $^{39}$ which consequently affects the soil's water storage, water movement and activities of soil biota. Stability of aggregate fractions and SOC vary with agricultural management practices and could be termed dynamic SPQ indicator. In all the land use types, SOC was the most dominant measured soil attribute. Therefore, appropriate management and monitoring of SOC can improve the quality of these soils from degrading or stable to aggrading. Hence, SOC can be selected subsequently as one critical attribute to monitor when SPQ indicators need to be studied in these soils. ${ }^{40}$

\section{Acknowledgements}

This study forms part of work carried out under the Nile Basin Development Challenge (NBDC) Program of the CGIAR Challenge Program on Water and Food (CPWF). The authors acknowledged with thanks the support of the Academy of Science for the Developing World (TWAS) to the first author, in form of an Associateship Fellowship, to undertake this study.

\section{Conflict of interest}

The author declares no conflict of interest.

\section{References}

1. Lal R. Soils and sustainable agriculture, a review. Agron Sustain Dev. 2008;28(1):57-64.

2. Karlen DL, Mausbach MJ, Doran JW, et al. Soil quality:a concept, definition and framework for evaluation. Soil Sci Soc Am J. 1997;61(1):410 .

3. EC (European Commission). COM 2006/231 2006. Communication from the Commission to the Council, The European Economic and Social Committee and the Committee of the Regions. Thematic strategy for soil protection, Commission of the European Communities, Brussels; 2006.

4. Toth G, Stolbovoy V, Montanarella L. Institute for environmental and sustainability, soil quality and sustainability evaluation. An integrated approach to support soil related policies in the European Union, A JRC Position Paper; 2007. 40 p.

5. Mueller L, Schindler U, Mirschel W, et al. Assessing the productivity function of a soils, a review. Agron Sustain Dev. 2010;30(3):601-614.

6. Reynolds WD, Drury CF, Yang ZM, et al. Land management effects on the near-surface physical quality of a clay loam soil. Soil Tillage Res. 2007;96(1-2):316-330.
7. Reeves DW. The role of soil organic matter in maintaining soil quality in continuous cropping systems. Soil Tillage Res. 1997;43(1-2):131-167.

8. Ogunwole JO, Chaudhary DR, Ghosh A, et al. Contribution of Jatropha curcas to soil quality improvement in a degraded Indian Entisol. Acta Agriculturae Scandinavica,Section B-Soil and Plant Science. 2008;58(3):245-251.

9. Dexter AR. Soil physical quality:part II. Friability, tillage, tilth and hard-setting. Geoderma. 2004;120(3-4):215-225.

10. Reynolds WD, Drury CF, Tan CS, et al. Use of indicators and pore volume-function characteristics to quantify soil physical quality. Geoderma. 2009;152(3-4):252-263.

11. Nyssen J, Poesen J, Deckers J. Land degradation and soil and water conservation in tropical highlands. Soil Tillage Res. 2009;103(2):197-202.

12. Gebre H, Molla D, Jayne TS, et al. Designing strategies to support a transformation of agriculture in Ethiopia. Food Security Report. 1997.

13. Yakovchenko V, Sikora LJ, Kaufman DD. A biologically based indicator of soil quality. Biology and Fertility of Soils. 1996;21(4):245-251.

14. Lal R. Soil quality and agricultural sustainability. USA: CRC Press; 1998. p. 3-12.

15. Chakraborty D, Garg RN, Tomar RK, et al. Soil physical quality as influenced by long term application of fertilizers and manure under maize-wheat system. Soil Sci. 2010;175(3):128-136.

16. Petersen RG, Calvin LD. Sampling. In: Klute A, et al. editors. Methods of soil analysis 1 Physical and Mineralogical methods. Madison, Wisconsin, USA: American Society of Agronomy-Soil Science Society of America; 1986;9:33-51.

17. Klute A. Water retention:laboratory methods. In: Klute A editor. Methods of soil analysis part 1, 2nd ed. Agronomy. 1986;9:635-662.

18. van Genuchten MTh. A closed-form equation for predicting the hydraulic conductivity of unsaturated soils. Soil Sci Soc of Am J. 1980;44:892898.

19. Mualem Y. Hydraulic conductivity of unsaturated soils:Prediction and formulas. In: Klute A editor. Methods of soil analysis part 1, physical and mineralogical methods. ASA, Madison, Wisconsin, USA; 1986. p. 799-823.

20. http://ars.usda.gov/Services/docs.htm?docid $=8952$

21. Gee GW, Bauder JW. Particle size analysis. In: Klute A editor. Methods of soil analysis, Part 1. 2nd ed. Madison, Wisconsin, USA: American Society of Agronomy; 1986. p. 383-411.

22. Nelson DW, Sommers LE. Total Carbon, organic carbon, and organic matter. In Page AL editor. Methods of soil analysis, part 2. Agronomy Monograph 9, Wisconsin, USA: Agronomy Society of America Madison; 1982. p. 539-579.

23. Kemper WD, Rosenau RC. Aggregate stability and size distribution. In Klute A editor. Methods of soil analysis:Part 1. 2nd ed. Agron Monogr 9 ASA, Wisconsin, USA: Madison; 1986. p. 425-442.

24. SPSS. Statistical Package for Social sciences. Release 18.0. SPSS Inc; 2010sw.

25. Kaiser HF. The varimax criterion in analytic rotation in factor analysis. Pychometrika. 1958;23(3):187-200. 
26. Ogunwole JO, Timm LC, Obidike EO, et al. Spatial analysis of smallscale heterogeneity in soil properties of a Savanna forest reserve and its implications for precision management. Proceedings of the 1st Workshop of the ICTP Soil Physics Associates. Abdus Salam International Centre for Theoretical Physics (ICTP)-International Centre for Eremology (ICE) Special Pre-Publication No. 1; 2011. p. 23-34.

27. Ogunwole JO, Ogunleye PO. Influence of long term application of organic and mineral fertilizers on quality of a savanna Alfisol. J Sustainable Agriculture. 2005;26(3):5-14.

28. Reynolds WD, Yang XM, Drury CF, et al. Effects of selected conditioners and tillage on the physical quality of a clay loam soil. Can J Soil Sci. 2003;83(4):381-393.

29. Drewry JJ. Natural recovery of soil physical properties from treading damage of pastoral soils in New Zealand and Australia:a review. Agric Ecosys Environ. 2006;114(2-4):156-169.

30. Carter MR. Temporal variability of soil macroporosity in a fine sandy loam under mouldboard ploughing and direct drilling. Soil \& Tillage Res. 1988;12(1):37-51.

31. Greenland DJ. Soil management and soil degradation. Journal of Soil Sci. 1981;32(3):301-322.

32. Sojka RE, Upchurch DR. Reservations regarding the soil quality concept. Soil Sci Soc Amer J. 1999;63(5):1039-1054.

33. Hall DGM, Reeve MJ, Thomasson AJ, et al. Water retention, porosity and density of field soils. Soil Survey Tech Monogr no. 9. Rothamsted, Harpenden, UK; 1977.
34. Doran JW, Mielke LN, Power JF. Microbial activity as regulated by soil water filled pore space. Symposium III-3, Ecology of Soil Microorganisms in the Microhabitat Environments III. Transactions of the 14th International Congress of Soil Science, Japan; 1990. p. 94-99.

35. Dexter AR, Czyz EA. Applications of S-theory in the study of soil physical degradation and its consequences. Land Degradation and Development. 2007;18(4):369-381.

36. Millan H, Tarquis AM, Perez LD, et al. Spatial variability patterns of some vertisol properties at a field scale using standardized data. Soil Till Res. 2012;120:76-84.

37. Shukla MK, Lal R, Ebinger M. Determining soil quality indicators by factor analysis. Soil Tillage Res. 2006;87(2):194-204.

38. Feller C, Albrecht A, Blanchart E, et al. Soil organic carbon sequestration in tropical areas. General considerations and analysis of some edaphic determinants for lesser Antilles soils. Nutr Cycl Agroecosyst. 2001;61(1-2):19-31.

39. Lawal HM, Ogunwole JO, Uyovbisere EO. Reciprocal relationships between aggregate stability and organic carbon characteristics in a forested ecosystem of northern Nigeria. Tropical and SubtropicalAgroecosystems. 2012;15(3):481-488.

40. Six J, Bossuyt H, De-Gryze S, Denef K. A history of research on the link between (micro) aggregates, soil biota and soil organic matter dynamics. Soil Till Res. 2004;79(1):7-31. 